\title{
IMPACT OF BANKING SERVICES ON CUSTOMER SATISFACTION IN NIGERIA BANKING SECTOR
}

\author{
Fatoki Jacob Obafemi Ph.D FCA \\ Department of Accounting and Finance \\ Ajayi Crowther University, Oyo \\ Nigeria.
}

DOI: http://dx.doi.org/10.38193/IJRCMS.2021.3406

\begin{abstract}
The study examined the impact of banking services on customer satisfaction. Customer's satisfaction plays crucial role in the success of banking sector, financial sector, business organization, production sector, firms, industries, small medium enterprises and all other areas of business. However, as far as banking sector is concerned, the success of banking sector depends upon corporate customers need and their expectations towards their banking services. Banking sector is a customer-oriented services provider.
\end{abstract}

The following objectives were discussed: to examine the extent to which the quality of bank services promote customer satisfaction and examine the extent to which customer service variables/factors (convenience, transaction method and system, pricing, product and services, reliability, tangibility, assurance, empathy and responsiveness) influence bank customer satisfaction.

Data were collected from diffident commercial banks in Nigeria and analysis was through descriptive and parametric statistical methods. This descriptive analysis involves the use of percentage analysis, while in section B-J, likert scale, mean and standard deviation was used, while parametric statistical method employed One sample test and Analysis of variance and it was discovered that the quality of bank services promote customer satisfaction.

More so, further findings revealed; customer satisfaction is a key performance indicator in the banking industry and customers' satisfaction has great influence on profitability of banks.

Hence, it therefore recommends, banks should use complaints resolution process to track and analyze customer complaints, ensure prompt response, thereby learning from complaints to improve their services and banks should also ensure effective delivery of services quality through the continuous provision of fast, reliable and error-free transaction to bank customers.

KEYWORDS: Satisfaction, Customers, Services, Banking sector, expectation. 


\subsection{Background of Study}

The goal of every organization is to meet the needs and the requirements of its stakeholders. Meeting the needs and the requirements of stakeholders will not only ensure the survival of the organization but also allow it to flourish. Customers are presumed to be one of the most important stakeholders in any organization because without them, organizations are not likely to succeed.

Customer satisfaction is actually a term most widely used in the business and commerce industry. It is a business term explaining about a measurement of the kind of products and services provided by a company to meet its customer's expectation. To some, this may be seen as the company's key performance indicator. In a competitive marketplace where businesses compete for customers, customer's satisfaction is seen as key differentiator and increasingly has become a key element of business strategy.

Furthermore, Commercial banks are established to provide financial services at a profit. The intense competition that exists in the market for financial services, presents a big challenge to the profitability of banking institutions of all sizes. The competition and saturation in the banking industry require banks to be more customer-focused. Customers are exposed to diverse choices and are much concerned about the value for their money.

However, Banks therefore, need to identify factors that influence customer satisfaction, and work towards them, better than competitors. Currently, there are about 22 licensed reconsolidated commercial banks jostling for customer ship in virtually all the 36 states in Nigeria. Business day, (2012).

More so, Customer's satisfaction plays crucial role in the success of banking sector, financial sector, business organizations, production sector, firms, industries, small medium enterprises and all other areas of business. However, as far as banking sector is concerned, the success of banking sector depends upon corporate customers need and their expectations towards their banking service. Banking sector is a customer oriented services provider. The main quality services offered and used by different banks in Nigeria comprised of electronic \& internet banking services and general services of banks which attracting customers.

Berry et al., (2000) posited that customer always use service quality characteristics of investigation, understanding and assurance for the assessment of service quality. These service quality characteristics are materialistic proficiencies, expression of employees and other expressions, convenience, transactions method and system; pricing, product and services are taken into account by customers before consumption of available service. 


\subsection{Statement of Problem}

The days of a customer adopting one product or company for life are long gone. With easy access and global competiveness, bank customers are often swayed by advertising and a chance of better deal/services. In the banking sector, quality levels are often comparable.

However, the major factor that separates competition in the banking sector is their level and quality of service. It is not unusual for customers to switch back and forth between banks simply because of pricing, a bad first impression or lack of quality services.

Furthermore, satisfaction is the customer evaluation of a product or service in terms of whether that product or service has met their needs and expectation.

Currently in Nigeria, banks customer demand efficient, fast convenient services, they want a bank that will meet their particular needs and support their business goal.

More so, it is a known fact banks still encounter problems in meeting customers expectation of service and customer satisfaction. Long queues and huge crowd in the banking hall can be highly devastating and discouraging most times. Adoption of current technology in banking operation especially in service delivery seems not to have achieve their aims has queues are still the order of the day in the banking halls. However, other problem that incapacitates the manner in which banks meet their customer expectations include, limited time for customer servicing, transaction errors, excessive bureaucracy, excessive operation cost and high delivery cost.

\subsection{Objectives of the Study}

The main objective of this study is to examine the effect of quality and reliable banking services on customers satisfaction in the banking industry

The study focused on the following specific objectives:

i. To examine the extent to which the quality of bank services promote customer satisfaction.

ii. To examine the extent to which customer service variables/factors.

(Convenience, transaction method and system, pricing, product and services, reliability, tangibility, assurance, empathy and responsiveness) influence bank customer satisfaction.

\subsection{Research Questions}

i. Will the quality of banking services promote customer satisfaction?

ii. Does convenience as a customer service variable influence bank customer satisfaction?

iii. Is there any significant relationship between transaction method and bank customer satisfaction? 


\subsection{Statement of Research Hypotheses}

$\mathrm{Ho}_{1}$ : There is no significant relationship between banking services and customer satisfaction.

$\mathrm{Ho}_{2}$ : Convenience will not enhance customer satisfaction.

Ho3: There is no significant relationship between transaction methods and customer satisfaction.

\subsection{Significance of The Study}

The significance of this study is characterized with enormous importance as the quality of banking services has become a predictor of customer satisfaction.

However, the study will sensitize the management of banks on the need to regularly conduct marketing research to monitor change in customers banking needs in designing future strategies for competitive advantage also with an insight into kinds of service bank customers find most appropriate for their banking needs.

Furthermore, the study will serve as a reference to Researchers or Students who may be interested to embark on further research study of this nature and also enhance their understanding as regards implication of bank services on customer satisfaction.

\subsection{Scope of the Study}

The study is restricted to Nigeria Banking Industry. The reach of this study will cover the Nigerian Banking System.

However, this study will shed more light on the importance of quality and reliable banking services as a pre-requisite and predictor of customer satisfaction in today's banking industry.

This study was divided into five chapters. The first section, which is the introduction, presents the background to the study, statement of the problem, objectives of the study and significance of the study among others. Section two reviewed existing literature on the impact of workforce diversity on organization performance. Section three explained the research methodology to be applied in the study. Section four shall focus on the data presentation and analysis while the concluding part of the study is section five where in a nutshell, the summary of the findings, the conclusion, and recommendations were presented.

\section{LITERATURE REVIEW}

\subsection{Banking Services in Nigeria: Overview}

Financial institutions play a crucial role in facilitating the accumulation and allocation of capital by channeling individual savings into loans to governments, businesses and individuals. In Nigeria, the role of the banking sector in capital concentration and distribution cannot be disputed. Credit crunch 
has affected the performance of many banks globally. Thus, institutions that adopt strategies to compete better than more likely to survive in the long run.

Furthermore, within the banking sector, customer loyalty to business in one way of keeping banking business competitive, providing high service quality is also critical for enhancing long-term relationships with customers, which is especially important in the competitive banking environment of modern banking (Camarero, 2007). Therefore, delivery quality service to customers is a must for success and survival in today's competitive banking environment (Samli and Frohlich, 1992). As regards banks, customer longevity can only be achieved through delivering high quality services (Lassar et al, 2000) especially under unregulated and volatile financial market conditions (Colgate and Lang, 2001). It is therefore imperative for banks to identify and manage the service quality dimensions which could lead to competitive advantage with their customers.

More so, Hinson and Hammond (2006) posited that, "with the passage of the universal banking law however, all types of banking can be conducted under a single corporate banking entity and this greatly reorganizes the competitive scopes of several banking products in Nigeria. Thus, reform and deregulation has brought the banking sector into the competitive arena in terms of customers and products. This means strategic management decisions should take into consideration factors that promote customer satisfaction, customer retention, customer loyalty, increased market share and firm profitability.

Kehinde (2011) asserted that, if the 25 deposit banks currently in Nigeria are to survive and be successful providers of financial service, they should apply practical approach to customer services. The customer should be seen as kings whose needs and expectations should form the centre-piece of banks activities. The excellent provision of these needs will guarantee customer satisfaction, good business performance and competitive advantage for the bank concerned.

He further stated that, during this post-consolidation era, the sophisticated and discerning bank customer will expect a good blend of the speed and personalized attention which the so called "new generation banks" are known for one hand and the security and caution usually associated with old generation bank on the other hand. Excellent customer services in a bank will put in place, machinery that ensure effective, efficient and smooth banking operations while the provision of professional banking advice in investment, cash flow planning and decisions are guaranteed. This will cause improved internal controls which will extensively reduce bank forgeries and fraud.

However, technology in service organizations is important for success. Some scholars have studied technology in service organizations from different perspectives. Harsh (1993) studied beneficial aspects of technology and identified. 
Five major benefits of technology to a service organization. First, the equipment could be employed in place of work force. Such substitution of equipment and machines for labour reduces cost of operation and increases efficiency.

Second, introduction of technology may help to achieve standardization in the quality of service. Third, higher service levels could be achieved by such blending of technology. Fourth, service organizations can maintain close links with their customers by hooking up in the computer networks such technologies permit one firm to link itself with the information system of the other hand, thereby, be in touch.

\subsection{Concept of Customer Satisfaction in Nigeria Banking Industry}

A customer can be defined as a user or potential user of banking services. A customer would include an account holder, or his representative, or a person carrying out casual business transactions with a bank, or a person who, on his own initiative, may come within the banking fold (Talwar Committee Report, 1976).

There are many factors that affect customer satisfaction. These factors include friendly employees, courteous employees, knowledgeable employees, helpful employees, accuracy of billing, billing timeliness, competitive pricing, service quality, good value, billing clarity and quick service Hanrkiranpal, (2006).

The efficiency of a banking sector depends upon how best it can deliver services to its target customers. In order to survive in this competitive environment and provide continual customer satisfaction, the providers of banking services are now required to continually improve the quality of services. It is seen that 5\% in insurance and brokerage, and $125 \%$ in the customer credit card market. Therefore, banks are now stressing on retaining customers and increasing market share (Chothani et al, 2004).

Furthermore, a favourable climate for excellent service manifests itself in employee behavior, for example, being attentive to customers, speaking favourably about the organization and its services. With frequent employee-customer contact, customers are more often exposed to such positive behaviours, which in turn, affect customer satisfaction.

\subsection{Concept of Bank Customer Service}

According to the America Bankers Association, customer service reflects the total approach of a staff to a customer, it is regarded as the altitude of professionalism, friendliness and helpfulness that satisfies customers and leads to repeat business or patronage. In banking, all staff should focus on 
efficient and effective customer service delivery which results into customer delight. However, none of the good plans of the service provider can be successful operationally without repeated patronage by customers.

It therefore goes from the above that for excellent service in a bank, every member of staff should be a marketer, strategic manager and a practitioner of total quality management Kehinde (2011).

Furthermore, according to Peter (2011), bank services could be conceptualized by visualizing it in four levels which will move the banking community mindset to creating unique experiences for customer at all times. These levels are:

(i) Core Bank Service: This provides the basic and fundamental benefits which make service to be of interest.

(ii) Expected Bank Service: This gives the minimum set of expectation of customer.

(iii) Augmented Bank Service: This is about offering services that are over and above the expectation of the customer or over what the customer is accustomed to.

(iv) Potential Bank Service: This is about everything which can be done with service that will be of utility to the customer.

Finally, the concept of bank customer service from the perspective of banking services provides a dynamic opportunity toward enhancing customer satisfaction by orchestrating bank services to create endless value for the customer.

\subsection{Relationship between Customer Service Variables/Factor and Customer Satisfaction}

The variables include: Convenience, transaction method and system, pricing, product and services, reliability, tangibility, assurance, empathy and responsiveness.

\subsubsection{Convenience and Customer Satisfaction}

Bank customers always appreciate quick, prompt, efficient and effective service which they will regard as excellent service. In this regard, the bank is required to provide an appropriate environment conducive for service delivery and which the customer feels wanted. Customers need enhanced time for transacting business with banks. Kehinde and Peters (2011).

Furthermore, KPMG report (2013) on Africa Banking industry customer satisfaction survey, posited that Technology is changing the way and manner we conduct our business. There has never been such a time in history, like now, when technology has transformed the finance world, especially banking, leaving customers yearning for more innovative products and service from their banks. With ATMs becoming almost ubiquitous in Nigerian cities, it is not surprising that it has been the fastest growing 
channel in recent years. Almost eight in 10 customers surveyed use the ATM and nearly two thirds of these people visit an ATM on a weekly basis with cash withdrawal and balance enquiry amongst the most common transactions customers perform via the ATM.

However, despite the proliferation of new channels in recent years, findings show that adoption of other alternate channels is still comparatively low with very few respondents saying they use internet banking (12 percent), POS 20 (10 percent), telephone banking (9 percent) and mobile payments (5 percent). That being said, the significant and rapid adoption of the ATM suggests that once internet banking and mobile payments take root great potential could be realized.

Finally in KPMG report, banking has changed radically with the advent of the internet and smart phones. Banks have kept pace by delivering various alternate channels. Customers are empowered to serve themselves anytime, anywhere using these channels and convenience is at the heart of making empowered to serve themselves anytime, anywhere using these channels and convenience is at the heart of making the channels available to them. The Automated Teller Machine (ATM), in particular, has gained traction by establishing itself as the fastest growing channel Nigeria and Africa as a whole while other channels lag behind in terms of usage by customers.

\subsubsection{Transaction Methods and Customer Satisfaction}

Peter (2011), posited that, bank can use cost price of service to attract customers where the bank management would be required to develop competitive prices that will ensure the good returns on their business.

Furthermore, KPMG report (2013) on Africa Banking industry customer satisfaction survey, posited that mobile penetration in Nigeria today is higher than that of the internet and is expected to continue to rise for the foreseeable future. The cost to serve is unquestionably lower via mobile than any other channel.

\subsubsection{Product and Services and Customer Satisfaction}

KPMG report (2013) on Africa Banking industry customer satisfaction survey, asserted that, Customers want less generic products and desire more bespoke identify their customer's needs based on their behaviours and thus create products that are flexible enough to meet their needs. Effective product innovation and management could be made possible with effective customer segmentation. With customer segmentation, banks divide their customer base into clusters with similar characteristics in order to provide value and sales propositions which are effective and unique to each segment. 
Customer segmentation could take into consideration geo-demographic parameters such as age, profession, income etc. personal preferences such as access to channel preferred payment method and channel preference could also help in customer segmentation. Another key insight is indentifying financial potential of customers based on their transactions with the bank and development products aimed at increasing business with such customers. This helps the customer feel special and creates the impression that the bank is forward thinking and also wants growth in his/her business.

\subsubsection{Pricing and Customer Satisfaction}

KPMG report (2013) on Africa Banking industry customer satisfaction survey, posited that while banks may be constrained by pressure to deliver shareholder results and market elements in their determination of rates offered to customers, they can help customers make smart choices in the form of advisory support and improve the overall customer experience. Transparency also emerged as a common theme in the results in the area of pricing. Respondents would like banks to be more proactive in notifying them of change in interest rates, tariffs and terms and conditions.

Finally in KPMG report, transparency in the banking sector has come to the forefront in recent times. The industry regulator in Nigeria has established a customer protection division to provide a platform through which bank customers can seek redress.

\subsubsection{Reliability and Customer Satisfaction}

The reliability construct in the SERVQUAL model represents the service provider's ability to perform the promised service dependably and accurately. This is achieved through keeping promises to do something providing right service, consistency of performance and dependability, service is performed right at the first time, the company keeps its promises in accuracy in billing and keeping records correctly, available merchandize and error-free sales transactions and records. Reliability also consists of accurate order fulfillment; accurate record; accurate quote; accurate in billing; accurate calculation of commissions; keep services promise. He also mentioned that reliability is the most important factor in banking service (Yang et al, 2003). The higher customers appreciate on reliability, the higher the overall evaluation of service quality, satisfaction and continuous loyalty towards service provider (Ndubisi, 2006).

\subsubsection{Tangibility and Customer Satisfaction}

Tangibility relates to the physical aspects or evidence of a service. Physical aspects include appearance of equipment and fixtures, physical facilities, materials associated with the service, appearance of personnel and communication materials, convenience of physical facilities and layouts. In addition to the appearances of the facilities, it also takes into account the convenience offered the customer by the layout of physical facilities (Ananth et al, 2011). The higher customers appreciate on the physical aspects, the higher the overall evaluation of retail service quality is (Bellini et al., 2005). 
Angur et al (1999) found that business premises should have a high standard of decoration and a nice environment to positively influence service quality which will consequently lead to customer loyalty. The physical service setting is a very important tangible factor that influences service quality perceptions.

For instance, Bitner (1992) focused on the elements under the control of businesses at the point of interaction between customers and the firm, arguing that these controllable elements can affect perceptions of service quality and encourage repeat patronage.

Bitner (1992) explained that the physical setting of the place of service, including not only visual aspects such as colour and texture, but also noise, odors, and temperature is of particular importance and capable of altering customer expectations and strongly influencing consumer responses and satisfaction.

Furthermore, Wakefield and Blodgett (1996) also found that service scope in terms of layout, aesthetics, electronic displays, seating, and cleanliness on customers' perceptions of service quality has a relatively consistent and strong effect on customer retention and their patronage intentions. They noted that the strongest element in the perception of service quality was the "aesthetic appeal of the facility architecture and décor," remarking that customers' first impressions of the facilities influence their overall assessment of the services.

Bonn \& Mathews (2007) posited that, substantial evidence that the designs of the physical setting and its associated sensory attributes can have a significant effect on customer satisfaction and on a customer's re-patronage decisions.

The professional appearance of staff is an important means of tangibilizing the intangible service products. However, the tangibles of a service or service provider can be represented by physical appearance of employees and other physical infrastructures. This has also seen the introduction of a dress code or uniform for bank employees across the country (Kim \& Jin, Brady and Cronin (2001) asserted that consumers react not only to products, but also to the features that accompany the product. They asserted that consumers make their purchase decision and respond to more than simply the tangible product or service being offered but respond to the total product. One of the most significant features of the total product is the place where it is bought or delivered. Atmosphere relates to the effort to design buying environments to produce specific emotional effects in the buyer that enhance his purchase probability. In some cases, the place, more specifically the atmosphere of the place, is more influential than the product itself in the purchase decision. In some cases, the atmosphere is the primary product. They called this "atmospherics" or "the effort to design buying environments to 
produce specific emotional effects in the buyer which enhance his purchase probability"

More so, the other tangibility aspect is the interior design of premises and facilities. The interior design of the premises and facilities influence customers' perception of service quality, customer satisfaction and loyalty. Studies on the influence of the physical interior design of the facility on service quality, customer satisfaction and patronage decisions are in support of this finding. Sherman et al, (1997) confirmed that the interior environments were important determinants of purchase behavior. Kalcheva and Weitz (2006) explained that the interior environment of business settings had an impact on consumer purchasing behavior, particularly on re-patronage intentions or decisions.

The interior environment can influence customer emotions especially in extended service transactions (Berry et al, 2006). Baker and Cameron (1996) identified three environmental components involved in waiting: ambient elements (non-visual sensory input), design elements (visual components), and social elements (the people in the service setting). The authors found that bright lighting, uncomfortable temperature, fast or loud music, oversaturated and warm colours, uncomfortable seating and glare create negative emotions and cause customers to overestimate wait times. Conversely, lower lighting levels, temperature within a comfort range, soft and slow music, light and cool colours and comfortable seating created positive emotions and caused customers to underestimate wait times. They concluded that the interior environment can enhance the consumer experience in extended service interactions by creating positive emotions and reducing negative emotions.

Finally, the adequacy of personnel and facilities are also aspects of tangibility that influence service quality perceptions. They affect the time taken by the business to deliver the service. Waiting time is a part of many service encounters and can influence service quality perceptions (Taylor, 1994; Baker and Cameron 1996; Brady and Cronin 2010). Taylor (1994) and Le Bel (2005) explained that in extended service transactions, where customers interact with service providers over long periods of time, emotions are of paramount importance and emotions generated at one stage in the service experience may influence customers' perceptions of later stages of the process (Dube and Menon 2000). When customers perceived waiting time as favourable, they perceive the service quality to be higher (Brady and Cronin, 2001). When they perceive waiting time as too long or too short, their evaluation of service quality declines (Taylor, 1994). All elements of the interior environment, including the physical setting and ambient conditions, function as service clues that give customers an indication of the quality of the service to be received (Reimer and Kuehn 2005) and become important in determining customer loyalty.

\subsubsection{Assurance and Customer Satisfaction}

The assurance construct consists of competence (possession of the required skills and knowledge to perform the service), courtesy (consideration for the customer's property, clean and neat appearance 
of public contact personnel), credibility and security of the employees and their ability to inspire trust and confidence.

According to Sadek et al. (2010), assurance means the polite and friendly staff, provision of financial advice, interior comfort, eases of access to account information and knowledgeable and experienced management team. This includes employees having knowledge to answer questions, inspiring confidence, providing prompt service, willing to respond to customer's requests, giving customers individual attention, showing consistent courtesy with customers and even treat customer properly on the phone. The higher customers appreciate personal interaction, the higher the overall evaluation of service quality is.

Furthermore, this dimension concerns how knowledgeable and courteous employees are to inspire confidence and trust from their customers. The assurance attributes are very much about the extent to which a consumer trusts a provider and whether or not they have the confidence in an organization to provide a service securely and competently. There is a substantial level of trust in the bank and its abilities were necessary to make the consumer comfortable enough to establish a banking relationship. Parasuraman, et al, (1991) included actions by employees such as always courteous, behavior instills confidence, and knowledge as prime elements of assurance.

More so, on the aspect of the feeling of safety when transacting with the bank, customers are concerned or interested in security issues regarding on-line, credit card, tele-banking, internet etc transactions. Security and safety are ranked highly in measuring feeling safe and secure whilst making transactions. This may be attributed to the nature of the services provided by banks. Customer face much greater risk in terms of fraud and identity theft in banking. This may explain the fact that banks do all they can to assure their customers those transactions with their organizations are safe and secure on whether employees always instill confidence in their bank customers, it is important to acknowledge the fact that customers want to trust and have confidence in the competence of the service provider's employees to deliver the service. The customer will not be satisfied if he/she does not feel assured about the competence of the service provider.

Finally, the courteous nature of the service provider's staff also influences the customer's assessment of service quality. The politeness of the employees is an important attribute for evaluating service quality because of the heavy interactional nature of the service. Often customer show demanding expectations for politeness of employees. The extensive contact and interactions between the customer and the employees makes it a key variable for service quality and perpetual re-purchase of product/usage of service i.e. customer loyalty. 


\subsubsection{Responsiveness and Customer Satisfaction}

Responsiveness is the determinant that defines the willingness to help customers and to provide prompt services. It is the desire and willingness to assist customers and deliver prompt service. It involves features such as the opening hours of the service provider, the politeness of the employees and the time the customer has to wait in order to get the service. In other words, it describes how quickly and affective the response to the customer is. Willingness to help customers is likely to have an important and positive effect on customer' perceived service quality and customer satisfaction in the banking industry.

Mengi (2009) explained that responsiveness is positively related to service quality, customer satisfaction and customer loyalty. It also involves understanding needs and wants of the customers, convenient operating hours, individual attention given by the staff, attention to problems and customers' safety in their transaction (Kumar et al, 2009). Mohammed and Shirley (2009) posited that bank services such as prompt communication to the customer are vital. Customers are concerned whether their bank will provide the right information to the right customers promptly. This as creates public confidence, and thus helps customers to make the right decisions at the right time. Responsiveness is likely to have an important and positive effect on customer satisfaction and loyalty Glaveli et al., (2006). The higher customers appreciate problem solving, the higher overall Evaluation of Service Quality Which Will Eventually Lead to Loyalty.

\section{METHODOLOGY}

Here, the researcher express the research method, data collection instrument, the population of study, sample size and sampling technique, and the method of data presentation and analyses employed in carrying out this research.

\subsection{Research Design}

Research design means the plan, structure and strategy of investigation conceived to provide answer to the research question and control possible variance. It also relates to the general approach adopted in executing a study.

The chosen designs for this study is public survey i.e. the collection of primary data through the use of questionnaires from the case study and thereafter the questionnaire element was entered into Microsoft Excel program and then imported to Statistical Package for Social Sciences programme (SPSS) to facilitate data analysis to test the effect of the independent variables (Banking services) on the dependent variable (customer satisfaction).

\subsection{Data Collection}

The researcher used primary Data in collecting a structural questionnaire consisting mainly of closed- 
ended questions and interviews.

The primary data used in this research work include interview with few Personnel of different commercial banks in Nigeria and the use of structured questionnaire filled by respondents who are personnel and customers of each particular banks.

\subsection{Source of Data}

The Data collected and analyzed are primary data. This form of data has result in sound evaluation of this article topic, giving credence to the underlying assumptions propounded.

\subsection{Data Analysis}

Data analysis method deals with how necessary data collected through primary source has been properly processed and presented for meaningful analysis. The method adopted to analyze data collected was less manual and more of computer aided method. The computer aided package known as Statistical Package for Social Science will be deployed to analyze data in the form of frequency tables, mean and standard deviation and hypothesis testing (T-test and Anova).

\section{Analysis Of Variance (ANOVA)}

Analysis of Variance (ANOVA) is a tool used in determining whether the difference in the means is significant enough to support the hypothesis of the study in preference to accepting the sample error or chance caused the different in the more than two means obtained by the two groups.

$$
\text { ANOVA F }=\frac{\text { MSB }}{\text { MSW }}
$$

Where $\mathrm{F}=$ Anova, $\mathrm{MSB}=$ means of between group, $\mathrm{MSW}=$ means of within group.

The ratio of MSB/MSW is the ratio of variances which results in the test statistics (i.e F statistics), needed to carry out the test.

Decision rule: At 0.05 level of significance, the null hypothesis (Ho) would be rejected if the calculated is greater than the tabulated and would be accepted if the reverse is the case that is if the calculated value is less than the tabulated.

\section{ONE SAMPLE T-TEST}

The One-Sample T Test procedure tests whether the mean of a single variable differs from a specified constant.

Statistics: For each variable: mean, sample size, standard deviation and standard error of the mean. For each pair of variables: correlation, average different in means, $t$ test and confidence interval for 
mean difference.

$$
\begin{aligned}
& \text { One Sample t-test } \\
& \mathrm{t}=\mathrm{D} / \mathrm{S} x^{\mathrm{t}}=\mathrm{D} / \mathrm{S} x \\
& \mathrm{D}=\mathrm{X}-\mathrm{V} \\
& \mathrm{S} x=\mathrm{S} / \sqrt{\mathrm{w}}_{\mathrm{W}} \\
& \mathrm{X}_{1}=\text { value of variable } \mathrm{X} \text { for I } \\
& \mathrm{W}_{1}=\text { weight for case } \\
& \mathrm{V}=\text { Test value } \\
& \mathrm{S} x=\text { Standard error of mean }
\end{aligned}
$$

With $(\mathrm{W}-1)$ degrees of freedom. A two-tailed significance level.

\subsection{Presentation and Analysis of Data According to Test of Hypotheses}

\section{Hypothesis 1}

In other to test for the first hypothesis of this study, the researcher made use of one sample t-test. The first hypothesis is stated below:

Ho1: There is no significant relationship between banking services and customer satisfaction

\begin{tabular}{|l|c|c|c|c|}
\hline \multicolumn{5}{|c|}{ Table 4.4.1 One-Sample Statistics } \\
\hline & $\mathbf{N}$ & Mean & $\begin{array}{c}\text { Std. } \\
\text { Deviation }\end{array}$ & $\begin{array}{c}\text { Std. Error } \\
\text { Mean }\end{array}$ \\
\hline $\begin{array}{l}\text { There exist significant relationship } \\
\text { between banking services and } \\
\text { customer satisfaction }\end{array}$ & 88 & 4.4091 & .82541 & .08799 \\
\hline
\end{tabular}

Source: SPSS 17, Analysis, author's computation February, 2021

Table 4.4.2 One Sample Test 
ISSN 2582-2292

Vol. 3, No. 04 July-Aug; 2021

\begin{tabular}{|c|c|c|c|c|c|c|}
\hline & \multirow[b]{2}{*}{$\mathbf{t}$} & \multirow[b]{2}{*}{ df } & \multirow{2}{*}{$\begin{array}{l}\text { Sig }(2- \\
\text { tailed) }\end{array}$} & \multirow{2}{*}{$\begin{array}{c}\text { Mean } \\
\text { Difference }\end{array}$} & \multicolumn{2}{|c|}{$\begin{array}{l}\text { 95\% Confidence Interval of } \\
\text { the Difference }\end{array}$} \\
\hline & & & & & Lower & Upper \\
\hline $\begin{array}{l}\text { There exist significant } \\
\text { relationship between banking } \\
\text { services and customer } \\
\text { satisfaction }\end{array}$ & 50.110 & 87 & .000 & 4.40909 & 4.2342 & 4.5840 \\
\hline
\end{tabular}

Source: SPSS 17 Analysis, author's computation February, 2021

The result from the table 4.4.1 shows that the mean value was 4.4091 with standard deviation of .82541 and the standard error mean of .08799 .

From the one-sample Test, table 4.4.2. The test t-value shows a value of 50.110 and at $95 \%$ confidence interval of the difference between the lower and upper limit.

The lower value shows 4.2342 and the upper value 4.5840. The result was significant at 2-tailed with a high percentage.

\section{CONCLUSION}

The tcal value of 50.110 is greater than the ttab of 1.98 . This shows that the null hypothesis is rejected and alternative hypothesis is accepted.

Therefore, the study concludes that there is significant relationship between banking services and customer satisfaction.

\section{Hypothesis 2}

In other to test for the second hypothesis of this study, the researcher made use of Analysis of Variance (Anova). The second hypothesis is stated below:

Ho2: Convenience will not enhance customer satisfaction

\begin{tabular}{|l|c|c|c|c|c|}
\hline \multicolumn{7}{|c|}{ ANOVA } \\
\hline \multicolumn{6}{|c|}{ Perceived convenience will enhance customer satisfaction } \\
\hline & $\begin{array}{c}\text { Sum of } \\
\text { Squares }\end{array}$ & df & $\begin{array}{c}\text { Mean } \\
\text { Square }\end{array}$ & F & Sig. \\
& & & \\
\hline
\end{tabular}




\begin{tabular}{|l|c|c|c|c|c|}
\hline Between Groups & 34.349 & 4 & 8.587 & 94.424 & .000 \\
\hline Within Groups & 7.548 & 83 & .091 & & \\
\hline Total & 41.898 & 87 & & & \\
\hline
\end{tabular}

Source: SPSS 17, Analysis, author's computation February, 2021

From the result, it is shown that the sums of squares for between Groups and within groups are 34.349 and 7.548 respectively.

The mean square shows a value of 8.587 and .091 respectively however, the F - Statistics value which helps to tell about the overall significant of a model and its good fit shows a value of 94.424 . This result was greater than the tabulated value of $2.45, \mathrm{v} 1=\mathrm{v} 2$ degree of freedom.

\section{CONCLUSION}

The result from the significant table shows it was highly significant. Hence we reject the null hypothesis ( $\mathrm{HO}$ ) convenience will not enhance customer satisfaction and accept the alternative hypothesis (H1). Therefore, convenience will enhance customer satisfaction.

Hypothesis 3

In other to test for the third hypothesis of this study, the researcher made us of Analysis of Variance (Anova). The third hypothesis is stated below:

Ho3: There is no significant relationship between transaction methods and customer satisfaction

\begin{tabular}{|l|c|c|c|c|c|}
\hline \multicolumn{7}{|l|}{ ANOVA } \\
\hline $\begin{array}{l}\text { There exists significant } \\
\text { satisfaction }\end{array}$ & $\begin{array}{c}\text { Sum of } \\
\text { Squares }\end{array}$ & df & $\begin{array}{c}\text { Mean } \\
\text { Square }\end{array}$ & F & Sig. \\
\hline & 37.644 & 4 & 9.411 & 105.052 & .000 \\
\hline Between Groups & 7.435 & 83 & .090 & & \\
\hline Within Groups & 45.080 & 87 & & & \\
\hline Total & & & & \\
\hline
\end{tabular}

Source: SPSS 17 Analysis, author's computation February, 2021

From the result, it is shown that the sums of square for between Groups and within groups are 37.664 and 7.435 respectively.

The mean square shows a value of 9.411 and .090 respectively however, the F-statistic value which helps to tell about the overall significant of a model and its good fit shows a value of 105.052. This 
result was greater than the tabulated value of $2.45, \mathrm{v} 1=\mathrm{v} 2$ degree of freedom.

\section{CONCLUSION}

The result from the significant table shows it was highly significant. Hence, we reject the null hypothesis (H0) there is no significant relationship between transaction methods and customer satisfaction and accept the alternative hypothesis (H1). Therefore, there is significant relationship between transaction methods and customer satisfaction.

\section{Summary of Findings, Conclusion and Recommendations}

This concluding section comprises of a summary of the research essay from the first chapter to the fourth chapter, conclusion is drawn from the findings and from the conclusion made; viable recommendations are addressed to Nigeria Banking Sector and directly to all banks to ensure satisfaction of customers.

\section{1 Summary of Study}

This study examines "the impact of banking services of customers' satisfaction". In the course of achieving this, the research work was divided into sections; each section provided unique and different information.

Chapter one includes: Background of the study, statement of problem, objectives of the study, relevant research questions to be answered, formulated hypothesis to be tested, significance of the study, scope and limitation of the study and definition of terms.

In an attempt to build up knowledge on this study, efforts were made to critically and resourcefully review the contributions of various authors; academically and professionally minded people on the topic.

The research methodology includes the use of questionnaires administered to personnel of commercial banks which was interpreted and analysed using percentages, tables, and likert scale through the aid of statistical package for social science (SPSS).

To test and provide the validity of the hypotheses, analysis of variance and one sample t-test was used on the research questions and hypothesis testing with degree of freedom. Conclusion was based on the decision rule of each statistical analysis.

\subsection{Summary of Findings}

In this final section, empirical findings were highlighted. The empirical findings are the actual findings that were obtained from respondent to questions pertaining to the study and subsequent analysis 
thereof, the result of the hypothesis and the totality of the observation during field work.

\subsection{Conclusion}

The researcher concludes by saying that customers always use service quality characteristics of investigation, understanding and assurance for the assessment of service quality. These services quality characteristics are materialistic proficiencies, expression of employees and other expressions, convenience, transaction method and system, pricing, product and services are taken into account by customers before consumption of available service.

From the research, the following were deduced:

That there is significant relationship between banking services and customer satisfaction.

(i) Convenience will enhance customer satisfaction.

(ii) There is significant relationship between transaction methods and customer satisfaction.

(iii) Bank products and services will influence customer satisfaction.

(iv) Pricing will sway customer satisfaction.

(v) There is significant relationship between reliability and customer satisfaction.

(vi) Tangibility will enhance customer satisfaction.

(vii) Empathy does have significant effect on customer satisfaction.

Bank therefore need to identify factors that influence customer satisfaction, and work towards them, better than competitors.

\subsection{Recommendations}

The following should also be done to ensure customer satisfaction:

(i) Banks should use complaint resolution process to track and analyze customer complaints, ensure prompt response, thereby learning from complaints to improve their services.

(ii) Training on stress management and public dealing should be imparted to the employees.

(iii) Bank could continuously improve all service quality dimensions such as tangibility, reliability, responsiveness, assurance and empathy.

(iv) Banks should regularly conduct marketing research to monitor the change in customer patterns and needs.

(v) Commercial bank should also ensure effective delivery of service quality through the continuous provision of fast, reliable and error-free transaction to bank customers.

(vi) Bank management should ensure that their branches and personnel courteous in manner and pleasant in outlook, as this will enhance continuous patronage of bank customers.

\section{REFERENCES}

Angur, Madhukar G., Nataraajan, Rajan and Jahera Jr, John S., (1999). Service Quality in the Banking 
Industry: An Assessment in A Developing Economy. International Journal of Bank Marketing, 17 (3): 116-123.

Bellini, C.G.P. Lunardi, G.L and Henrique J.L. (2005). Service quality in banks: Insights from the Brazilian Experience. Journal of Internet Banking and Commerce, 10(3).

Berry (1988). A model of customer retention of dissatisfied business services customers. Managing Service Quality, 17(3), 298-316.

Bitner, M.J. (1992), "Servicescapes: the impact of physical marketing, Vol. 56, pp 57-71.

Brady, M.K. and Cronin, J.J Jr (2001), "Some new thoughts on conceptualizing perceived service quality: a hierarchical approach" Journal of Marketing, Vol. 65, pp. 34-39.

Carman, J.M. (2007) "Consumer perceptions of service quality: an assessment of the SERQUAL dimensions" Journal of Retailing, Vol. 66, No. 1, pp 33-35. i

Colgate and Lang, 2001 Market-Based Management: Strategies for growing customer value and profitability. 5th edition, Pearson, Prentice Hall.

Godse VT (1997). Banking technology: Challenges ahead for banks. IBA Bulletin, 68(4): 180-182.

Harkiranpal, S. (2006), "The importance of customer satisfaction in relation to customer loyalty and retention" UCTI Working Paper.

Harsh V.V. (1993). Marketing of Services. New Delhi: Global Business Press.

Hinson and Hammond (2006) "Service quality and satisfaction: the moderating role of service" European Journal of Marketing, Vol. 34, Nos 11/12, pp. 1338-52.

Kaltcheva, V.D., and B.A. Weitz (2006). When should a retailer create an exciting store environment? Journal of Marketing, 70, 107.

Kaynak, E., Kucukemiroglu, O., \& Odabasi, Y. (1991). Commercial bank selection in Turkey, International Journal of Bank Marketing, 9(4), 30-39.

Kehinde and Peter (2011) Excellent Customer Service in the Nigerian Banking Subsector Postconsolidation Era, Journal of the Chartered Institute of Bankers of Nigeria, Akure Branch, Vol. 2, No. 2, January, 2006.

Kim, S., \& Jin, B. (2002). Validating the retail service quality scale for US and Korean customers of discount stores: An exploratory study, Journal of Services Marketing 16(2/3), 223 - 237.

KPMG report (2013) on Africa Banking Industry Customer Satisfaction Survey.

Lassar et al 2000 Empirical assessment of SERVQUAL scale "Journal of Business Research, No. 24, pp $253-268$.

Mengi, P., (2009) Customer Satisfaction with Service Quality: An Empirical Study of Public and Private Sector Banks. IUP Journal of Management Research, 8(9): 7-17.

Ndubisi, N.O. (2006) Relationship marketing and customer loyalty. Marketing Intelligence, 25 (1) 98 106.

Parasuraman, A., 1991 “The service-quality puzzle”, business Horizons, Vol. 31, No. 5, pp. 35-43. Samli and Frohlich, (1992) "Redefining customer loyalty, the customer's way” Ivey Business Journal (Jan/Feb), pp. 14-19. 
Sherma, N., \& Patterson, P.G. (1997) Switching costs, alternative attractiveness and experience as moderators of relationship commitment in professional, consumer services. International Journal of Service Industry Management, 11(5), 470-490. http://dx.doi.org/10.1108/09564230010360182.

Wakefield, K.L., \& Blodgett, J.G. (1996). "The Effects of the Servicescape on Customers' Behavioural Intentions in Leisure Service Settings," Journal of Services Marketing 10(6), 45-61.

Yang et al (2003), "Understanding the salience of cultural dimensions on relationship marketing, its underpinnings and aftermaths," Cross Cultural Management, Vol. 11 No. 3, pp. 7089.

Arora (2011) Service with a difference: A comparative analysis of private and public sector banks. Prestige Journal of Management and Research, 8 (1-2): 17-29.

Chotani PY, Siva P, Narayanan L (2004). From <Error! Hyperlink reference not valid> (Retrieved November 3, 2008).

Ehigie, B.O. (2006). Correlates of customer loyalty to their bank: a case study in Nigeria International Journal of Bank Marketing, 24(7), 494-508.

Glaveli, N., Petridou, E. Liassides, C., and Spathis, C. (2006). Bank Service Quality evidence from five Balkan countries. Managing Service Quality: Global Trends and Challenges in Services, 16(4) 380-394. 